\title{
Continuous Bioethanol Production Using Uncontrolled Process in a Laboratory Scale of Integrated Aerobic-Anaerobic Baffled Reactor
}

\author{
Margono Margono ${ }^{1 *}$, Mujtahid Kaavessina1', Mior Ahmad Khushairi Mohd Zahari², \\ Anwaruddin Hisyam² \\ ${ }^{1}$ Chemical Engineering Department, Faculty of Engineering, Universitas Sebelas Maret, \\ JI. Ir Sutami 36 A, Kentingan Jebres, Surakarta, Jawa Tengah 57126, Indonesia \\ 2 Faculty of Chemical and Natural Resources Engineering, Universiti Malaysia Pahang, \\ Lebuh Raya Tun Razak 26300 Kuantan, Malaysia \\ *Corresponding author, e-mail: margono@ft.uns.ac.id
}

Received: 08 July 2019, Accepted: 23 August 2019, Published online: 20 November 2019

\begin{abstract}
The expensiveness of bioethanol has made it unattractive and uncompetitive for alternative energy sources. Therefore, several ways to reduce the production cost of bioethanol become interesting topics, e.g. increasing its productivity. This research investigated the performance sensitivity of a laboratory scale of integrated aerobic-anaerobic baffled reactor (IAABR) towards the residence time. The ethanol productivity was monitored to know the optimum residence time. The difference residence times were varied between at $19.2 \mathrm{~h}$ and $26.7 \mathrm{~h}$ by using difference volume of fermenters i.e. 10 and $100 \mathrm{l}$, respectively. Molasses as a medium was fed into a reactor containing one compartment of aerobic fermentation and three compartments of anaerobic fermentation. Total sugar and bioethanol concentration were measured for each compartment to determine the production yield to sugar consumption and bioethanol productivity. The fermentation process was conducted at $30{ }^{\circ} \mathrm{C}$, medium $\mathrm{pH}(4-5)$, and feed sugar concentration of $170 \mathrm{~g} / \mathrm{l}$. The results showed that the optimum residence time in this investigation range is $19.2 \mathrm{~h}$. The ethanol productivity was recorded at $4.63 \mathrm{~g} / \mathrm{l} . \mathrm{h}$ and the production yield to sugar was obtained at $46 \%$ (equivalent to $86 \%$ of theoretical yield) with average feeding of molasses at $0.52 \mathrm{l} / \mathrm{h}$.
\end{abstract}

Keywords

bioethanol, production cost, molasses, productivity, theoretical yield

\section{Introduction}

The depletion of petroleum resources is a serious problem for the future. Moreover, the rate of depletion is accelerated with growing volume of vehicle and machinery equipment. Additionally, this high petroleum consumption is also accelerated by the growth of various products from petroleum-based, such as plastics. This problem must be considered to maximize added value and to control the speed of depletion. Using petroleum for chemical derivative other than energy is the best option to maximize the value of petroleum. Meanwhile, fulfilling the demand of energy, a renewable energy resource is encouraged. Bioethanol, as a renewable resource of energy, is the most developed renewable energy to date for gasoline substitution (petroleum-based fuel) [1].
In fact, Indonesia is facing an obstacle in bioethanol utilization because of the bioethanol price is more expensive than that of petroleum. Therefore, reducing bioethanol price becomes a significant contribution to accelerating the application of bio-based fuel. One of which is productivity improvement in the fermentation. Two aspects have been studied i.e. fermentation using immobilized cell or free cell and fermentation using batch, fed-batch, or continuous method.

The traditional raw material (i.e. molasses) for ethanol production is still interesting to study but in immobilized cell system. It could be blended with Olive oil mill wastewaters (OOMWs) and resulted ethanol productivity of $2.8 \mathrm{~g} / \mathrm{l} . \mathrm{h}$ when processed using immobilized 
Saccharomyces cerevisiae [2]. Ghorbani et al. [3] also studied immobilized S. cerevisiae to improve conversion of cane molasses into ethanol and it resulted productivity of $2.39 \mathrm{~g} / \mathrm{l}$.h. However, it must be recognized that development of immobilized cells has some constraints, so it should be something interest to develop higher performance process with suspended cell system.

Bioethanol productions from starch or lignocellulosic feedstocks were usually done by simultaneous saccharification and fermentation (SSF) or separate hydrolysis and fermentation (SHF). It was investigated through fermentation using immobilized cell or free cell and yet attractive to study further. It is reported that immobilized cell and SSF method could produce higher productivity than the SHF method using free cell. Liu and Lien [4] reported bioethanol productivity of $0.21 \mathrm{~g} / \mathrm{l}$.h by SSF method using co-immobilized cell and $0.06 \mathrm{~g} / \mathrm{l}$.h by SHF method using co-suspension of free cell. Other research of bioethanol production from lignocellulosic feedstocks also showed better performance for semi SSF than that of SHF method. Semi SSF required 24 hours shorter than SHF to achieve an equal bioethanol concentration [5]. However, the SHF process using polyvinyl alcohol (PVA) immobilized Zymomonas mobilis showed better productivity when used to produce bioethanol from lignocellulosic feedstock, i.e., $3.04 \mathrm{~g} / \mathrm{l} . \mathrm{h}$ higher than SSF process which was $1.31 \mathrm{~g} / \mathrm{l} . \mathrm{h}[6]$.

Other investigation aspects of bioethanol productivity improvement were the process configuration, i.e., batch, fed batch, or continuous process. The best batch process (commercial process at PT Indoacidatama Tbk.) resulted in $10 \%(\mathrm{v} / \mathrm{v})$ bioethanol for 57 hours fermentation period or equivalent to productivity of $1.38 \mathrm{~g} / \mathrm{l}$.h bioethanol [7]. However, the productivity must be improved due to the associated price of IDR14,000 (before taxes), which was much higher than the gasoline price of IDR. 7650. The other process strategies, fed batch or continuous, were noticed to be more productive. This is the reason why many recent studies were exploring fed batch and continuous process to increase fermentation productivity.

Liu and Lien [4] could successfully increase productivity of SHF method from $0.21 \mathrm{~g} / \mathrm{l} . \mathrm{h}$ (flask culture) to $0.91 \mathrm{~g} / \mathrm{l} . \mathrm{h}$ (continuous culture in vertical mass flow bioreactor). In the same research, the best productivity of $1.33 \mathrm{~g} / \mathrm{l}$.h was obtained in an integrated continuous bioreactor and repeated batch method using sodium alginate immobilized cell. Unfortunately, sodium alginate gel bead had short life time which is only 12 days of running and it will swell and damage the characteristics of immobilized cell. Whereas immobilization cost is expensive.

The advantage of continuous culture compared to the batch culture was also shown by other fermentation processes. In acetone-butanol-ethanol production, continuous culture and repeated batch culture were already carried out and it resulted in $0.63 \mathrm{~g} / \mathrm{l} . \mathrm{h}$ (continuous) and $0.57 \mathrm{~g} / \mathrm{l} . \mathrm{h}$ (repeated batch) [8]. The highest productivity was achieved when the fermentation was carried out by combining continuous culture with repeated batch culture.

This research investigated the effect of residence time towards bioethanol productivity of continuous process using integrated aerobic-anaerobic baffled reactor (IAABR). We utilized an uncontrolled process in order to minimize the operational cost of fermenter (reactor).

\section{Experimental setup \\ 2.1 Medium}

Starter medium composition (in g/l): Yeast extract $10, \mathrm{NH}_{4} \mathrm{Cl}$ $0.13, \mathrm{CaCl}_{2} \cdot \mathrm{H}_{2} \mathrm{O} 0.06, \mathrm{MgSO}_{4} \cdot 7 \mathrm{H}_{2} \mathrm{O} 0.12$, and glucose 10 .

Production medium was cane molasses containing total sugar of $51 \% \mathrm{w} / \mathrm{w}$ and diluted using tap water to total sugar of $170 \mathrm{~g} / \mathrm{l}$. It was boiled for 30 minutes and the $\mathrm{pH}$ was adjusted to $4-5$.

\subsection{Microorganism}

Fermiol $^{\circledR}$ (Saccharomyces cerevisiae strain No DY 7221 DSM collection) was used as culture starter. It was stored in a cool $\left(5\right.$ to $\left.15^{\circ} \mathrm{C}\right)$ and dry place.

\subsection{Equipment}

The unit of fermentation equipment included feed storage, product storage, and integrated aerobic-anaerobic baffled reactor (IAABR). The unit of fermentation apparatus is shown in (Fig. 1).

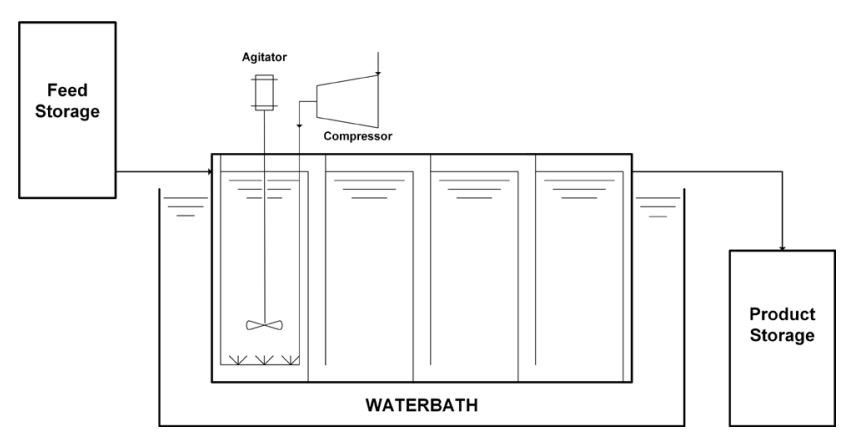

Fig. 1 Unit of fermentation apparatus 


\subsection{Experiment}

The experiments were divided into two process phases, i.e. batch process and continuous process. The batch process was initiated by filling the reactor with 101 of molasses medium, $\mathrm{pH}$ of $4-5$ and temperature of $30{ }^{\circ} \mathrm{C}$. The first compartment (A) was inoculated with $250 \mathrm{~mL}$ inoculum starter of $S$. cerevisiae and incubated for 21 hours aerobically. The continuous process started after the batch process on the flowrate of feeding $0.52 \mathrm{l} / \mathrm{h}$ (equivalent to residence time of 19.2 hours). The compartment A was always kept in aerobic phase with agitation of $100 \mathrm{rpm}$. The sampling was taken periodically and analyzed to measure the concentration of total sugar and bioethanol. The results was come from duplicate and presented in the average value. Further, this result was compared to our previous research with difference volume of reactor [9].

\subsection{Analysis}

Total sugar was measured by Dubois method [10]. Bioethanol was measured by density method and verified by GC (gas chromatography) method.

\section{Results and discussion}

Molasses was considered as the carbon source. This substrate has been established as carbon substrate in fermentation industries e.g. bioethanol industry. Meanwhile, $S$. cerevisiae was the ethanol producer for molasses medium. The usage of molasses medium and $S$. cerevisiae was able to avoid any problems caused by the uncertainty of incompatibility between microbe and medium. Hence, this research is purposely to evaluate the performance of IAABR on producing bioethanol.

Performance of bioreactor is indicated by four parameters i.e. capacity of sugar (substrate) feeding rate $(1 / h)$, bioethanol produced $(\% \mathrm{w} / \mathrm{w})$, productivity $(\mathrm{g} / \mathrm{l} . \mathrm{h})$, and yield of bioethanol to sugar or efficiency of bioethanol produced from sugar (\%). To evaluate bioethanol production process, the profile of residual sugar (Fig. 2) and related bioethanol production were determined (Fig. 3). Data shown in Fig. 2 and Fig. 3 are the average value of experiment results and uncertainty level of each chart is represented by standard deviation. Average values of the standard deviation for Fig. 2 are 7.1, 8.1, 9.9 and 4.5 for chart A, B, C and D respectively. Meanwhile, values of 5.7, 8.8, 10.0 and 9.7 are the standard deviation for Fig. 3 and sequentially for chart A, B, C and D.

\subsection{Sugar feeding rate and consumption}

The initial profile of residual sugar as presented in compartment A (Fig. 2) shows that the drastic decrease was observed from 15 to 21 hours of fermentation. This interval time corresponded to the batch fermentation to develop yeast inoculum for continuous bioethanol production. Hereafter, distributing inoculum was done into four compartments A, B, C, and D. This activity required about three hours and the continuous process step were started at fermentation time of 24 hours. The residual sugar at the initial continuous process was detected between 43-46 g/l.

The continuous process was performed by feeding molasses medium gravitationally to examine the lower production cost. The uncontrolled feeding process resulted in fluctuation of residual sugar concentrations along the process and in all of the compartments. However, the average residual sugar in each of compartment tended to decrease from compartment A to D, i.e., 45.2, 44.2, 37.9, and $37.9 \mathrm{~g} / 1$, respectively. The residual sugar in compartment D was high enough. High sugar concentration indicated two possibilities, i.e. the feeding rate was too fast or the sugar feeding concentration was too high. Hence, further exploration to get better process condition was necessary.

The total fermentation time was $351 \mathrm{~h}$ including the batch phase of $21 \mathrm{~h}$, the transition phase of $3 \mathrm{~h}$, and the continuous phase of $327 \mathrm{~h}$. From overall fermentation time, the production process was only in the continuous phase. The average flow rate of feeding was $0.52 \mathrm{l} / \mathrm{h}$, while the sugar feeding concentration was $170 \mathrm{~g} / 1$. As a consequence, the feeding sugar for $327 \mathrm{~h}$ was $27.141 \mathrm{~g}$. This was much higher rather than the commercial batch process of $8050 \mathrm{~g}$ sugar for $351 \mathrm{~h}$ fermentation time (7 batch cycles of 101 medium containing $115 \mathrm{~g}$ sugar/l). However, it was necessary to optimize because the residual sugar coming out from the compartment D was still high, i.e. $37.9 \mathrm{~g} / \mathrm{l}$, indicating a significant amount of sugar as waste.

\subsection{Bioethanol production and productivity}

For The main parameter of yeast capability was the achieved concentration of bioethanol achieved by this process. The high concentration of ethanol was limited by the ethanol tolerance of the yeast, i.e. $9-13 \%(\mathrm{w} / \mathrm{w})$ [11]. The profile of bioethanol (Fig. 3) showed that compartment A was the fastest to achieve the steady state, followed by B, C, and D. The average bioethanol in compartment A was $78.85 \mathrm{~g} / 1$ achieved at 49 hours, in 

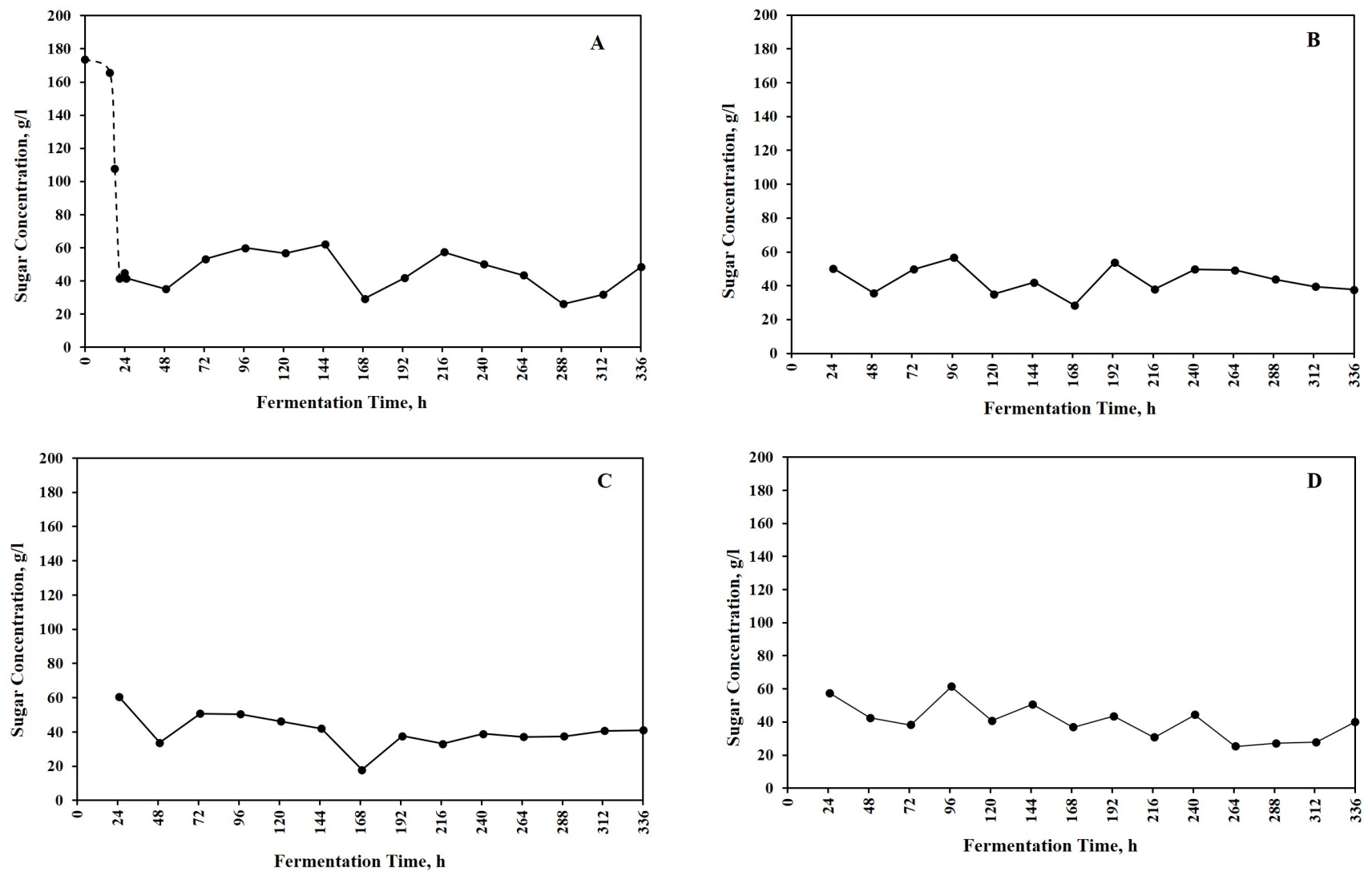

Fig. 2 Sugar concentration (g/1) in the compartment A, B, C, and D during continuous phased (Standard deviation: A: 7.1 ; B: 8.1 ; C: 9.9 ; D: 4.5 )
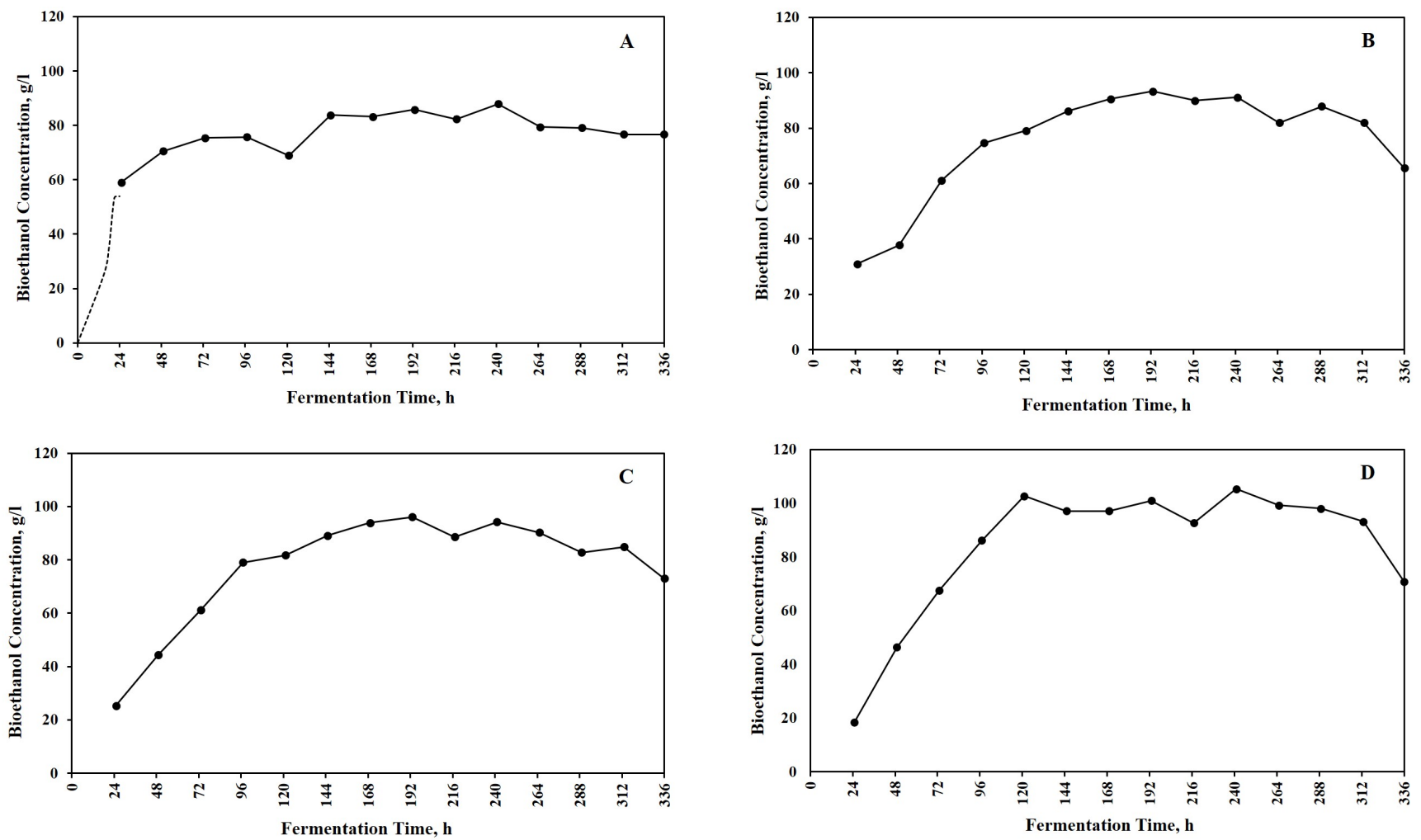

Fig. 3 Bioethanol concentration in each compartment of A, B, C, and D during continuous fermentation (Standard deviation: A: 5.7 ; B: 8.8 ; C: 10.0 ; D: 9.7) 
compartment B was $81.94 \mathrm{~g} / 1$ achieved at the time of 73 hours, in compartment $\mathrm{C}$ was $84.54 \mathrm{~g} / 1$ achieved at the time of 97 hours, and $92.55 \mathrm{~g} / 1$ in compartment D at the time of 121 hours. The production of bioethanol started to fall down at 313 hours of production time.

Bioethanol production for 14 days fermentation was $13.44 \mathrm{~kg}$. This indicated that yield of bioethanol to total sugar was $0.41(\mathrm{w} / \mathrm{w})$ or equivalent to $76.2 \%$ theoretical yield of ethanol/sucrose (the theoretical yield is $0.538 \mathrm{~g}$ ethanol/g sucrose), while productivity of bioethanol for 14 days fermentation was $4.63 \mathrm{~g} / \mathrm{l} . \mathrm{h}$. The commercial batch process in PT Indoacidatama Tbk converted cane molasses medium containing $150 \mathrm{~g} / \mathrm{l}$ total sugar into $10 \%$ $\mathrm{v} / \mathrm{v}$ bioethanol for 57 hours fermentation time [7]. This represented that productivity of bioethanol for the batch proses was $1.38 \mathrm{~g} / \mathrm{l}-\mathrm{h}$ and the yield was $97.8 \%$ theoretical yield ethanol/sucrose. Comparing continuous process in IAABR to the batch process showed the superiority of IAABR productivity. However, the commercial batch process was better in the higher yield ethanol/sugar.

\subsection{Productivity of bioreactor}

The theoretical yield of bioethanol-sucrose could be calculated by the stoichiometric reaction of sucrose-glucose conversion to ethanol (Eq. (1)).

$$
\mathrm{C}_{12} \mathrm{H}_{22} \mathrm{O}_{11}+\mathrm{H}_{2} \mathrm{O} \rightarrow \mathrm{C}_{6} \mathrm{H}_{12} \mathrm{O}_{6} \rightarrow 2 \mathrm{C}_{5} \mathrm{H}_{5} \mathrm{OH}+2 \mathrm{CO}_{2}
$$

Based on this stoichiometric of reaction, theoretical yield of sucrose to bioethanol is $53.8 \%(\mathrm{w} / \mathrm{w})$. If the actual yield was $41 \%$, this indicated that the actual yield of the process was $76.2 \%$ of theoretical yield.

The performance of IAABR resulted from this study is attractive to be developed in bioethanol production. The concentration of bioethanol in broth was $11.8 \%(\mathrm{v} / \mathrm{v})$. The bioethanol productivity of IAABR was $4.63 \mathrm{~g} / \mathrm{l}$.h or 3.4 times higher than that of the industrial batch process (Table 1). Further optimization is necessary to improve the performance of IAABR.

Table 2 shows the various bioethanol production processes. Generally, the production of bioethanol through continuous process gives higher productivity than that of batch process. This study gave 2-3 times higher productivity. Equally compared, Bouallagui et al. [12] gave higher productivity as the results of higher dilution rate. However, this condition created lower ethanol concentration in the effluent compared to this experiment. The concern would be essential due to the energy requirement in purification process. Compared to Tang et al. [13], that was using comparable dilution rate, the productivity of this study was lower. One of the reasons was that because they were using genetically hybrid yeast with improved activity while this research used untreated yeast. It showed that the performance of yeast greatly affected the productivity of ethanol. In addition, this finding was

\begin{tabular}{lcc}
\multicolumn{3}{c}{ Table 1 Bioethanol Productivity in each compartment IAABR } \\
\hline Compartment Feed & Bioethanol $(\mathrm{g} / \mathrm{l})$ & Productivity $(\mathrm{g} / \mathrm{l} . \mathrm{h})$ \\
\hline A & 78.86 & 3.73 \\
B & 81.94 & 3.74 \\
C & 84.54 & 3.81 \\
D & 92.55 & 4.63 \\
\hline
\end{tabular}

Table 2 Productivity of bioethanol production using batch and continuous process

\begin{tabular}{|c|c|c|c|c|c|c|c|c|}
\hline No & Reactor & Carbon source/ sugar & $\begin{array}{l}\text { Working } \\
\text { Volume, } 1\end{array}$ & Microorganism & $\begin{array}{c}\text { Life } \\
\text { Time, h }\end{array}$ & $\begin{array}{c}\text { Bioethanol, } \\
\mathrm{g} / 1\end{array}$ & $\begin{array}{c}\text { Productivity, } \\
\text { g/l.h }\end{array}$ & Ref. \\
\hline 1 & Batch fermentor & molasses/150 g/l & $\begin{array}{c}\text { Commercial } \\
\text { plant }\end{array}$ & S. cerevisiae & 57 & 78.90 & 1.38 & {$[7]$} \\
\hline 2 & Spinner bottle & glucose $/ 20 \%$ & 0.3 & S. cerevisiae KD2 & 50 & 94.68 & 1.89 & {$[14]$} \\
\hline 3 & Shaken flask & glucose $/ 40 \mathrm{~g} / 1$ & 0.25 & S. cerevisiae BY4742 & 48 & 65.36 & 1.35 & {$[15]$} \\
\hline 4 & Erlenmeyer flask & $\begin{array}{l}\text { Sweet sorghum } \\
\text { juice/240 g/1 }\end{array}$ & 0.35 & $\begin{array}{l}\text { Immobilized } S . \\
\text { cerevisiae NP02 }\end{array}$ & 70 & 109.34 & 1.52 & {$[16]$} \\
\hline 5 & Lab. scale-IAABR & molasses/256 g/1 & 10 & S. cerevisiae & 19.2 & 92.55 & 4.63 & This study \\
\hline 6 & CSTR & molasses $/ 50 \mathrm{~g} / 1$ & 1 & S. cerevisiae & 2 & 11.60 & 5.8 & {$[12]$} \\
\hline 7 & CSTR & molasses & 2 & S. cerevisiae $\mathrm{KF}-7$ & 1.25 & 30.00 & 24.0 & {$[13]$} \\
\hline 8 & Pilot scale-IAABR & molasses/256 g/1 & 100 & S. cerevisiae & 26.7 & 62.70 & 2.31 & [9] \\
\hline 9 & Shaken flask & molasses/140 g/l & - & S. cerevisiae & 52 & 68.50 & 1.32 & {$[17]$} \\
\hline
\end{tabular}


opening the future of IAABR development to use various kind of yeast to increase its productivity.

The IAABR was evidently prospective for mass production scale. The study showed that the productivity of IAABR was higher than that of any batch process. Moreover, IAABR embodied simple reactor design that conclusively reduced capital investment. In addition, IAABR could work properly without $\mathrm{pH}$ control thus minimized the production cost.

Table 2 also showed briefly our previous result when using the pilot scale of IAABR. The pilot scale volume of IAABR is 1001 with an average feeding of molasses at $3.75 \mathrm{l} / \mathrm{h}$. It means that the residence time of pilot scale is $26.7 \mathrm{~h}$. Compared to the laboratory scale which had residence time of $19.2 \mathrm{~h}$, the ethanol productivity of the pilot scale is lower. It may be explained that the longer residence time gives a longer opportunity of ethanol to accumulate in the compartment of reactor. This longer accumulation of ethanol causes the inhibition of fermentation

\section{References}

[1] Da Silva Jr, A., Hauber, J., Cancino, L., R., Huber, K. "The research octane numbers of ethanol-containing gasoline surrogates", Fuel, 243, pp. 306-313, 2019.

https://doi.org/10.1016/j.fuel.2019.01.068

[2] Nikolaou, A., Kourkoutas, Y. "Exploitation of olive oil mill wastewaters and molasses for ethanol production using immobilized cells of Saccharomyces cerevisiae", Environmental Science and Pollution Research, 25(8), pp. 7401-7408, 2018.

https://doi.org/10.1007/s11356-017-1051-6

[3] Ghorbani, F., Younesi, H., Sari, A. E., Najafpour, G. "Cane molasses fermentation for continuous ethanol production in an immobilized cells reactor by Saccharomyces cerevisiae", Renewable Energy, 36(2), pp. 503-509, 2011.

https://doi.org/10.1016/j.renene.2010.07.016

[4] Liu, Y. K., Lien, P. M. "Bioethanol production from potato starch by a novel vertical mass-flow type bioreactor with a co-cultured-cell strategy", Journal of the Taiwan Institute of Chemical Engineers, 62, pp. 162-168, 2016.

https://doi.org/10.1016/j.jtice.2016.01.027

[5] Cotana, F., Cavalaglio, G., Gelosia, M., Coccia, V., Petrozzi, A., Ingles, D., Pompili, E. "A comparison between SHF and SSSF processes from cardoon for ethanol production", Industrial Crops and Products, 69, pp. 424-432, 2015.

https://doi.org/10.1016/j.indcrop.2015.02.064

[6] Wirawan, F., Cheng, C. L., Kao, W. C., Lee, D. J., Chang, J. S. "Cellulosic ethanol production performance with SSF and SHF processes using immobilized Zymomonas mobilis", Applied Energy, 100, pp. 19-26, 2012.

https://doi.org/10.1016/j.apenergy.2012.04.032 due to the molasses concentration is lower. And it may be also as reported by Skupin and Metzger [18] that there was an inhibitory effect of product (ethanol) concentration to the microorganism cells metabolism.

\section{Conclusion}

The experiments showed that an uncontrolled continuous process of bioethanol production was properly run in the IAABR. The feeding rate of $0.52 \mathrm{l} / \mathrm{h}$ (residence time of $19.2 \mathrm{~h}$ ) containing sugar of $170 \mathrm{~g} / \mathrm{l}$ resulted bioethanol concentration $11.8 \%(\mathrm{v} / \mathrm{v})$. This result was related to the bioethanol productivity of $4.63 \mathrm{~g} / 1 . \mathrm{h}$ or equivalent to 3.4 times of commercial batch process. It also had higher result than the pilot scale with residence time of $26.7 \mathrm{~h}$ resulting productivity of $2.31 \mathrm{~g} / \mathrm{l}$.h. Meanwhile the yield of bioethanol to sugar was $41 \%(\mathrm{w} / \mathrm{w})$ which was equivalent to $76.2 \%$ of theoretical yield ethanol/sucrose. The IAABR was operated for 14 days of fermentation without contamination.

[7] Ruslina, M. Y. D. "Laporan kerja praktek PT. Indo Acidatama. Tbk." (Practical work report at PT Indo Acidatama, Tbk), BSc, Chemical Engineering Department, University of Indonesia, 2012. (in Indonesian)

[8] Dolejš, I., Krasňan, V., Stloukal, R., Rosenberg, M., Rebroš, M. "Butanol production by immobilised Clostridium acetobutylicum in repeated batch, fed-batch, and continuous modes of fermentation", Bioresource Technology, 169, pp. 723-730, 2014.

https://doi.org/10.1016/j.biortech.2014.07.039

[9] Margono, Kaavessina, M., Dyartanti, E. R. "Performance investigation of a pilot scale integrated aerobic-anaerobic baffle reactor for continuous ethanol production process under various sugar-feeding rates", Energy Exploration and Exploitation, 36(1), pp. 149-165, 2018.

https://doi.org/10.1177/0144598717723645

[10] DuBois, M., Gilles, K. A., Hamilton, J. K., Rebers, P. A., Smith, F. "Colorimetric method for determination of sugars and related substances", Analytical Chemistry, 28(3), pp. 350-356, 1956. https://doi.org/10.1021/ac60111a017

[11] Gray, W. D. "The Acclimatization of Yeast to High Concentration of Glucose: The Subsequent Effect Upon Alcohol Tolerance", Journal of Bacteriology, 52(6), pp. 703-709, 1946. [online] Available at: https://www.ncbi.nlm.nih.gov/pmc/articles/PMC518259/[Accessed: 07 July 2019]

[12] Bouallagui, H., Touhami, Y., Hanafi, N., Ghariani, A., Hamdi, M. "Performance comparison between three technologies for continuous ethanol production from molasses", Biomass and Bioenergy, 48, pp. 25-32, 2013.

https://doi.org/10.1016/j.biombioe.2012.10.018 
[13] Tang, Y. Q., An, M. Z., Zhong, Y. L., Shigeru, M., Wu, X. L., Kida, K. "Continuous ethanol fermentation from non-sulfuric acid-washed molasses using traditional stirred tank reactors and the flocculating yeast strain KF-7", Journal of Bioscience and Bioengineering, 109(1), pp. 41-46, 2010. https://doi.org/10.1016/j.jbiosc.2009.07.002

[14] Dombek, K. M., Ingram, L. O. "Ethanol Production during Batch Fermentation with Saccharomyces cerevisiae: Changes in Glycolytic Enzymes and Internal pH", Applied and Environmental Microbiology, 53(6), pp. 1286-1291, 1987. [online] Available at: https://www.ncbi.nlm.nih.gov/pmc/articles/PMC203856/ [Accessed: 07 July 2019]

[15] Lin, Y., Zhang, W., Li, C., Sakakibara, K., Tanaka, S., Kong, H. "Factors affecting ethanol fermentation using Saccharomyces cerevisiae BY4742", Biomass and Bioenergy, 47, pp. 395-401, 2012. https://doi.org/10.1016/j.biombioe.2012.09.019
[16] Laopaiboon, L., Nuanpeng, S., Srinophakun, P., Klanrit, P., Laopaiboon, P. "Ethanol production from sweet sorghum juice using very high gravity technology: Effects of carbon and nitrogen supplementations, Bioresource Technology, 100(18), pp. 4176-4182, 2009.

https://doi.org/10.1016/j.biortech.2009.03.046

[17] Khoja, A. H., Ali, E., Zafar, K., Ansari, A. A., Nawar, A., Qayyum, M. "Comparative study of bioethanol production from sugarcane molasses by using Zymomonas mobilis and Saccharomyces cerevisiae", African Journal of Biotechnology, 14(31), pp. 2455-2462, 2015. https://doi.org/10.5897/AJB2015.14569

[18] Skupin, P., Metzger, M. "Stability analysis of the continuous ethanol fermentation process with a delayed product inhibition", Applied Mathematical Modelling, 49, pp. 48-58, 2017. https://doi.org/10.1016/j.apm.2017.04.025 